NASA/TM-2004-212962
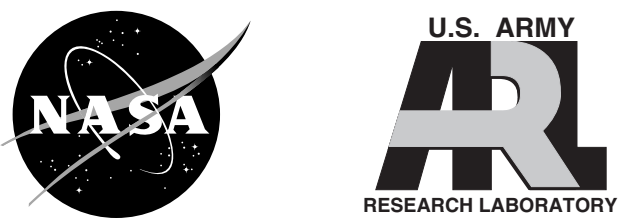

Furnace Cyclic Oxidation Behavior of Multi-Component Low Conductivity Thermal Barrier Coatings

Dongming Zhu

U.S. Army Research Laboratory, Glenn Research Center, Cleveland, Ohio

James A. Nesbitt and Charles A. Barrett

Glenn Research Center, Cleveland, Ohio

Terry R. McCue

QSS Group, Inc., Cleveland, Ohio

Robert A. Miller

Glenn Research Center, Cleveland, Ohio 
Since its founding, NASA has been dedicated to the advancement of aeronautics and space science. The NASA Scientific and Technical Information (STI) Program Office plays a key part in helping NASA maintain this important role.

The NASA STI Program Office is operated by Langley Research Center, the Lead Center for NASA's scientific and technical information. The NASA STI Program Office provides access to the NASA STI Database, the largest collection of aeronautical and space science STI in the world. The Program Office is also NASA's institutional mechanism for disseminating the results of its research and development activities. These results are published by NASA in the NASA STI Report Series, which includes the following report types:

- $\quad$ TECHNICAL PUBLICATION. Reports of completed research or a major significant phase of research that present the results of NASA programs and include extensive data or theoretical analysis. Includes compilations of significant scientific and technical data and information deemed to be of continuing reference value. NASA's counterpart of peerreviewed formal professional papers but has less stringent limitations on manuscript length and extent of graphic presentations.

- TECHNICAL MEMORANDUM. Scientific and technical findings that are preliminary or of specialized interest, e.g., quick release reports, working papers, and bibliographies that contain minimal annotation. Does not contain extensive analysis.

- CONTRACTOR REPORT. Scientific and technical findings by NASA-sponsored contractors and grantees.
- CONFERENCE PUBLICATION. Collected papers from scientific and technical conferences, symposia, seminars, or other meetings sponsored or cosponsored by NASA.

- SPECIAL PUBLICATION. Scientific, technical, or historical information from NASA programs, projects, and missions, often concerned with subjects having substantial public interest.

- TECHNICAL TRANSLATION. Englishlanguage translations of foreign scientific and technical material pertinent to NASA's mission.

Specialized services that complement the STI Program Office's diverse offerings include creating custom thesauri, building customized databases, organizing and publishing research results ... even providing videos.

For more information about the NASA STI Program Office, see the following:

- Access the NASA STI Program Home Page at http://www.sti.nasa.gov

- E-mail your question via the Internet to help@sti.nasa.gov

- Fax your question to the NASA Access Help Desk at 301-621-0134

- Telephone the NASA Access Help Desk at 301-621-0390

- Write to:

NASA Access Help Desk

NASA Center for AeroSpace Information 7121 Standard Drive

Hanover, MD 21076 
NASA/TM-2004-212962
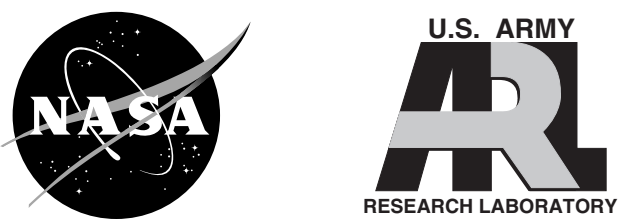

\section{Furnace Cyclic Oxidation Behavior of Multi-Component Low Conductivity Thermal Barrier Coatings}

Dongming Zhu

U.S. Army Research Laboratory, Glenn Research Center, Cleveland, Ohio

James A. Nesbitt and Charles A. Barrett

Glenn Research Center, Cleveland, Ohio

Terry R. McCue

QSS Group, Inc., Cleveland, Ohio

Robert A. Miller

Glenn Research Center, Cleveland, Ohio

National Aeronautics and

Space Administration

Glenn Research Center 


\section{Acknowledgments}

This work was supported by the NASA Ultra-Efficient Engine Technology (UEET) Program. The authors are also grateful to Ralph G. Garlick and George W. Leissler, NASA Glenn Research Center, for their assistance in the x-ray diffraction analysis, and the preparation of plasma-sprayed thermal barrier coatings, respectively.

Available from

NASA Center for Aerospace Information 7121 Standard Drive

Hanover, MD 21076
National Technical Information Service 5285 Port Royal Road Springfield, VA 22100 


\title{
Furnace Cyclic Oxidation Behavior of Multi-Component Low Conductivity Thermal Barrier Coatings
}

\author{
Dongming Zhu \\ U.S. Army Research Laboratory \\ National Aeronautics and Space Administration \\ Glenn Research Center \\ Cleveland, Ohio 44135 \\ James A. Nesbitt and Charles Barrett \\ National Aeronautics and Space Administration \\ Glenn Research Center \\ Cleveland, Ohio 44135 \\ Terry R. McQue \\ QSS Group, Inc. \\ Cleveland, Ohio 44135 \\ Robert A. Miller \\ National Aeronautics and Space Administration \\ Glenn Research Center \\ Cleveland, Ohio 44135
}

\begin{abstract}
Summary
Ceramic thermal barrier coatings will play an increasingly important role in advanced gas turbine engines because of their ability to further increase engine operating temperatures and reduce cooling, thus helping achieve future engine low emission, high efficiency and improved reliability goals. Advanced multi-component zirconia-based thermal barrier coatings are being developed using an oxide defect clustering design approach to achieve the required coating low thermal conductivity and high temperature stability. Although the new composition coatings were not yet optimized for cyclic durability, an initial durability screening of the candidate coating materials was conducted using conventional furnace cyclic oxidation tests. In this paper, furnace cyclic oxidation behavior of plasma-sprayed zirconia-based defect cluster thermal barrier coatings was investigated at $1163{ }^{\circ} \mathrm{C}$ using $45 \mathrm{~min}$ hot cycles. The ceramic coating failure mechanisms were studied using scanning electron microscopy (SEM) combined with X-ray diffraction (XRD) phase analysis after the furnace tests. The coating cyclic lifetime is also discussed in relation to coating processing, phase structures, dopant concentration, and other thermo-physical properties.
\end{abstract}

\section{Introduction}

Ceramic thermal barrier coatings (TBCs) have received increased attention for advanced gas turbine engine applications. The advantages of using TBCs include increased engine efficiency by allowing higher gas temperatures and improved reliability from lower component temperatures. Future TBC systems will be more aggressively designed for the thermal protection of engine hot-section components, thus allowing significant increase in engine operating temperatures, fuel efficiency and reliability. However, the increases in engine temperature can raise many coating durability issues (refs. 1 and 2). The 
development of next generation lower thermal conductivity and improved thermal stability TBCs becomes a necessity for advancing the ultra-efficient and low emission gas turbine engine technology.

Many new TBC materials have been proposed to achieve low thermal conductivity and high temperature capability of the coating systems (refs. 3 to 20). The two most important material categories for advanced TBC applications include novel oxide compound materials such as pyrochlore-, perovskiteand magetoplumbite-type ceramics (refs. 3 to 11), and advanced multicomponent oxide-doped $\mathrm{ZrO}_{2}$ and $\mathrm{HfO}_{2}$ solid solution based ceramics (refs. 11 to 18). In particular, $\mathrm{ZrO}_{2}$ and $\mathrm{HfO}_{2}$ solid solution based thermal barrier coatings, co-doped with the primary stabilizer $\mathrm{Y}_{2} \mathrm{O}_{3}$ and additional paired rare-earth defect cluster oxides using an oxide defect clustering design approach, have been found to possess significantly lower thermal conductivity and improved sintering resistance at high temperatures than current state-ofthe-art $\mathrm{ZrO}_{2}-(7-8) \mathrm{wt} \% \mathrm{Y}_{2} \mathrm{O}_{3}$ TBCs (refs. 11, 14 to 16). The solid solution based oxide thermal barrier coatings may potentially also have better cyclic durability because of their possible higher toughness values, as compared to the relatively low toughness oxide compound materials (ref. 8). The purpose of this paper is to report the furnace cyclic oxidation performance of plasma-sprayed multi-component zirconia-based thermal barrier coatings as a function of dopant concentration and processing variations. The ceramic coating failure mechanisms were investigated using scanning electron microscopy (SEM) combined with X-ray diffraction (XRD) phase analysis after the furnace cyclic tests. The coating cyclic lifetime is discussed in relation to coating processing, phase structures, dopant concentration, and other thermo-physical properties. It should be mentioned that although these coatings were not optimized for cyclic durability in terms of the compositions and processing, the early stage furnace cyclic oxidation screening tests of a large number of the new coating systems helped to guide coating design directions using more sophisticated compositional modification and processing optimization approaches. The coating thermal conductivity and cyclic oxidation life information will be used to down-select coatings for the laser-simulated engine high-heat-flux thermal gradient cyclic testing at much higher surface temperatures, which is a critical step for the development of advanced high performance coating systems.

\section{Experimental Materials and Methods}

Plasma-sprayed multi-component rare-earth $\left(\mathrm{RE}_{2} \mathrm{O}_{3}\right)$ oxide doped $\mathrm{ZrO}_{2} \mathrm{TBCs}$ were used for the furnace cyclic oxidation tests. The coatings were the $\mathrm{ZrO}_{2}$-based oxides, stabilized with the primary yttria $\left(\mathrm{Y}_{2} \mathrm{O}_{3}\right.$ ) dopant and/or paired Group A (such as $\mathrm{Nd}_{2} \mathrm{O}_{3}, \mathrm{Gd}_{2} \mathrm{O}_{3}$, and $\mathrm{Sm}_{2} \mathrm{O}_{3}$ ) and Group B (such as $\mathrm{Yb}_{2} \mathrm{O}_{3}$, $\mathrm{Sc}_{2} \mathrm{O}_{3}$ ) rare-earth oxide co-dopants (refs. 13 to 15). The total dopant concentration for the coatings ranged from 4.5 to $52.5 \mathrm{~mol} \%$. These multi-component oxide cluster coatings were found to have significantly lower thermal conductivities and better thermal stability in a wide (especially in the lower) total dopant concentration range as compared to the conventional $\mathrm{ZrO}_{2}-8 \mathrm{wt} \% \mathrm{Y}_{2} \mathrm{O}_{3}\left(8 \mathrm{YSZ}\right.$, or $\left.\mathrm{ZrO}_{2}-4.55 \mathrm{~mol}_{2} \mathrm{Y}_{2} \mathrm{O}_{3}\right)$ coatings. The optimum thermal conductivity region was reported in the range of 6 to $13 \mathrm{~mol} \%$ total dopant concentrations, believed to be near the tetragonal/cubic phase boundary region of the zirconia alloys, where 50 to 60 percent conductivity reductions have been observed for some of the best coating systems after the 20 hour thermal exposure at $1316^{\circ} \mathrm{C}$ (ref. 15).

The defect cluster coating systems consisted of a $120 \mu \mathrm{m}$ thick NiCoCrAlY or NiCrAlY bond coat and a 180 to $250 \mu \mathrm{m}$ thick ceramic top coat which were plasma-sprayed on to a $25.4 \mathrm{~mm}$ diameter and 3.2 mm thick nickel base superalloy, René N5 disk substrates. The bond coat was processed using the typical low-pressure-plasma-spray technique. The ceramic top coats with various designed compositions, were air plasma-sprayed using pre-alloyed powders. The ceramic powders were first spray-dried, and then plasma-reacted and spheroidized (two passes) to ensure that the appropriate phase homogeneity and particle size distributions were obtained. Several batches of powders from different vendors were used in the studies. The plasma-spraying parameters and conditions for processing the oxide cluster top-coats were the same as those for the standard baseline $\mathrm{ZrO}_{2}-8 \mathrm{wt} \% \mathrm{Y}_{2} \mathrm{O}_{3}$ coating. Some processing variations, including removing very fine particles ( $<37 \mu \mathrm{m}$ in size), and plasma-spraying duplex layer ceramic 
coatings that consisted of a $50 \mu \mathrm{m}$ first-layer $\mathrm{ZrO}_{2}-8 \mathrm{wt} \% \mathrm{Y}_{2} \mathrm{O}_{3}$ near the bond coat interface and a regular thickness (180 to $250 \mu \mathrm{m}$ ) cluster oxide coating, were also used to investigate the effects of processing and coating structure on the cyclic lifetime.

Furnace cyclic tests were carried out at $1163^{\circ} \mathrm{C}\left(2125^{\circ} \mathrm{F}\right)$ using either a tube or a box furnace in air with 45 min hot-time cycles. The cooling times were 15 minutes for the tube furnace test and 3 hours for the box furnace, and the specimens were cooled to $\sim 120^{\circ} \mathrm{C}$ after each cooling cycle. The specimens were inspected in 10 or 20 cycle intervals. The coating cycle lifetime was determined by the cycle number when the coating failure occurred. The failure criterion used was the observed delamination or spallation region being equal or larger than 20 percent of the total coating area. The spalled coating specimens were examined using XRD for phase analysis, and SEM for detailed failure morphology analysis.

\section{Results and Discussion}

\section{Furnace Cyclic Oxidation Life of the Multi-Component Coatings}

Figure 1 shows the furnace cyclic test results for the plasma-sprayed multi-component oxide defect cluster coatings, the baseline $\mathrm{ZrO}_{2}-8 \mathrm{wt} \% \mathrm{Y}_{2} \mathrm{O}_{3}$, and other yttria-stabilized-zirconia (YSZ) binary coatings. The variation of coating cyclic lifetime from batch to batch is obvious. In addition, the cyclic life of the oxide coatings generally decreased with increasing total dopant concentration. The baseline $\mathrm{ZrO}_{2^{-}}$ $8 \mathrm{wt} \% \mathrm{Y}_{2} \mathrm{O}_{3}$ coating generally showed good furnace cyclic durability. The multi-component cluster oxide coatings showed evidence of having better cyclic oxidation durability than yttria-doped zirconia binary coatings at given dopant concentrations. The early failure and short cyclic lifetime of the first batch (batch 1) coating systems including the baseline $\mathrm{ZrO}_{2}-8 \mathrm{wt} \% \mathrm{Y}_{2} \mathrm{O}_{3}$, was attributed to the dense top coat (ref. 19), and also the NiCoCrAlY bond coat (ref. 20). Both factors can result in large thermal- and oxidationinduced stresses in the ceramic coating, thus significantly weakening the ceramic/bond coat interface region due to extensive cracking during thermal cycling.

The cyclic durability of the initial batch cluster coatings was considerably improved (life increased by 2 to 3 times) using some processing modifications. Less dense oxide cluster coatings were processed by removing the fine particles (with the particle sizes below the -325 mesh or $37 \mu \mathrm{m}$ ) from the plasmaspraying powders. Improved interface adhesion and thermal shock resistance of the very low conductivity oxide coatings were also attempted by adding a thin intermediate layer of $\mathrm{ZrO}_{2}-8 \mathrm{wt} \% \mathrm{Y}_{2} \mathrm{O}_{3}$ coating $(\sim 50 \mu \mathrm{m})$ between the NiCoCrAlY bond coat and the oxide cluster top coatings. The two processing approaches proved effective in improving the coating life for the present furnace cyclic tests.

The further modified batch 2 and 3 coatings, which used more favorable spray particle size distributions and a NASA in-house improved NiCrAlY bond coat, showed better cyclic durability than the initial processed coatings. As can be seen from figure 1, even the single-layered oxide cluster coatings (without the $\mathrm{ZrO}_{2}-8 \mathrm{wt} \% \mathrm{Y}_{2} \mathrm{O}_{3}$ interlayer) generally achieved better cyclic life than the duplex $\mathrm{ZrO}_{2}-$ $8 \mathrm{wt} \% \mathrm{Y}_{2} \mathrm{O}_{3} /$ oxide cluster two-layered coatings processed in batch 1 . The cyclic life improvement was more pronounced for the lower dopant ( $6 \mathrm{~mol} \%$ total dopant) concentration coatings. The oxide cluster coating life reached as high as 150 cycles for the $13.5 \mathrm{~mol} \%$ dopant coating and 300 cycles for the $6 \mathrm{~mol} \%$ total dopant coating. The multi-component cluster oxide coatings showed the better cyclic durability than the yttria-stabilized-zirconia (YSZ) binary oxide coatings (solid squares) at the equivalent dopant concentrations. 
The optimum processed (batch 4) coatings, which also used the improved NiCrAlY bond coat, showed excellent cyclic resistance probably due to more optimum coating processing conditions and resulting coating microstructures. It can be seen from figure 1 that, even for some medium high dopant concentration coatings ( 13.5 and $15.8 \mathrm{~mol} \%$ total dopant), the coating life reached near $450-500$ cycles. Under the same furnace cyclic tests, the baseline $\mathrm{ZrO}_{2}-8 \mathrm{wt} \% \mathrm{Y}_{2} \mathrm{O}_{3}$ coatings (solid circles) under the improved processing conditions (batches 2 to 4 ) had the furnace life ranging from 140 to 420 cycles. The higher dopant $\mathrm{YSZ}$ binary coatings $\left(\mathrm{ZrO}_{2}-10 \mathrm{~mol} \% \mathrm{Y}_{2} \mathrm{O}_{3}, \mathrm{ZrO}_{2}-12 \mathrm{~mol} \% \mathrm{Y}_{2} \mathrm{O}_{3}\right.$, and $\left.\mathrm{ZrO}_{2}-30 \mathrm{~mol}_{0} \mathrm{Y}_{2} \mathrm{O}_{3}\right)$ showed poor cyclic resistance. The life of these binary $\mathrm{ZrO}_{2}-\mathrm{Y}_{2} \mathrm{O}_{3}$ coatings seemed less dependent on the processing conditions and optimizations. The failure morphologies and mechanisms for the coating will be further discussed later in this paper.

It should be mentioned that in this study, both tube furnace and box furnace tests generally showed good agreement in the coating life results. The slightly longer coating life observed in the box furnace tests may be due to the much slower cooling rate ( 3 hours cooling for box furnace and 15 minutes cooling for the tube furnace) which can reduce some of the thermal shock effect for the very low conductivity and slightly higher thermal expansion cluster oxide coatings. The thermal conductivity values and thermal expansion coefficients of the multi-component oxide cluster coating are listed in table 1.

The strong processing and composition effects on the coating cyclic life observed in this study indicate considerable challenges, but they also offer great opportunities, for the development of advanced, multi-component, high performance thermal barrier coatings. The test results demonstrate the importance of the coating processing and composition optimizations. The beneficial effects of the added rare earth cluster oxides also shows great promise in significantly improving coating cyclic durability.

\section{Failure Morphologies and Mechanisms}

Figure 2 shows typical SEM micrographs of spalled coating surface morphologies and cross-sections for several coating systems after the furnace cyclic testing. It can be seen that the oxide coatings generally failed in a mixed mode, i.e., the coatings were spalled under thermal cycling by a combined mechanism where the coating delaminations occurred within the ceramic top coat near the ceramic/metal bond coat interface (ceramic failure), and through the thermally grown alumina scales at the interface (oxide scale

failure). The oxide scale related failure was generally involved with the separation of the ceramic/alumina scale interface, as well as the cracking/delamination within the oxide scales. However, sometimes the failure occurred at the scale/bond coat interface where the bare metal surface was exposed after the coating spallation.

The ceramic coatings with optimized processing to control coating porosity, demonstrated longer cyclic life. The ceramic coatings possessing a more optimum porosity, were more elastically compliant but still retaining the adequate coating strength. The coatings can thus have reduced thermal cyclic stresses, originating either from the thermal expansion mismatch between the ceramic and metal substrate or from the bond coat oxidation during the cycling, without significantly deteriorating the coating mechanical properties. In addition to the coating processing effect, the relatively low yttria dopant $\mathrm{ZrO}_{2}-$ $8 \mathrm{wt} \% \mathrm{Y}_{2} \mathrm{O}_{3}$ coating and certain multi-component cluster dopant coatings exhibited excellent thermal cycling resistance, implying also a strong compositional effect on coating cyclic performance. Since the high cyclic stress region is primarily located near the ceramic/bond coat interface (the observed ceramic failure is usually within about 10 to $20 \mu \mathrm{m}$ above the interface), applying a thin layer of a more cyclic stress resistant low dopant coating such as $\mathrm{ZrO}_{2}-8 \mathrm{wt} \% \mathrm{Y}_{2} \mathrm{O}_{3}$ to the interface and forming a duplex coating system would greatly improve the overall coatings furnace cycling performance.

The longer life coatings, due to either improved processing or modified multi-component rare earth dopant compositions, typically showed a more predominant interface scale failure, as indicated by the increasing area fraction of interface scale failure region after the furnace cyclic testing. Low magnification SEM images of the spalled surface morphologies for two distinctive performance coatings, 
i.e., a low toughness, poor cyclic resistance $\mathrm{ZrO}_{2}-30 \mathrm{ol} \% \mathrm{Y}_{2} \mathrm{O}_{3}$ (cyclic life 10 to 20 cycles), and a long cyclic life $\mathrm{ZrO}_{2}-13.5 \mathrm{~mol} \%$ (Y, Gd, $\left.\mathrm{Yb}\right)_{2} \mathrm{O}_{3}$ coating (cyclic life 430 cycles), are shown in figure 3 to exemplify the failure mechanisms.

As mentioned in the cyclic results discussion, the coatings with lower dopant concentrations generally exhibited a better cyclic resistance, suggesting a possibly more toughened phase structure in the lower concentration region. The X-ray diffraction results in figure 4 shows the phase structure changes as a function of the dopant concentration for several oxide thermal barrier coatings. It can be seen that the $\mathrm{ZrO}_{2}-8 \mathrm{wt} \% \mathrm{Y}_{2} \mathrm{O}_{3}$ and $\mathrm{ZrO}_{2}-6 \mathrm{~mol} \%(\mathrm{Y}, \mathrm{Nd} / \mathrm{Sc})_{2} \mathrm{O}_{3}$ coatings had the predominant tetragonal phase structure. The $\mathrm{ZrO}_{2}-10 \mathrm{~mol} \%(\mathrm{Y}, \mathrm{Nd}, \mathrm{Yb})_{2} \mathrm{O}_{3}$ and $\mathrm{ZrO}_{2}-12 \mathrm{~mol} \% \mathrm{Y}_{2} \mathrm{O}_{3}$ coatings had mostly the cubic structure, because the tetragonal peak split of $\mathrm{t}(400)$ and $\mathrm{t}(004)$ observed for lower concentration coatings started to disappear at this composition. The higher dopant concentration coatings, such as $\mathrm{ZrO}_{2}-16 \mathrm{~mol} \%$ $(\mathrm{Y}, \mathrm{Re})_{2} \mathrm{O}_{3}$ and $\mathrm{ZrO}_{2}-30 \mathrm{~mol} \% \mathrm{Y}_{2} \mathrm{O}_{3}$, had a fully-cubic phase structure. The fact that the coating cyclic life typically decreases with dopant concentration may suggest that the tetragonal phase has a better cyclic resistance and thus possibly higher fracture toughness; and the observed coating life decreases, corresponding to the tetragonal phase fraction decreasing, with increasing the dopant concentrations.

The better thermal cyclic resistance (thus maybe the expected higher fracture toughness) of the supersaturated tetragonal $t^{\prime}$ phase structure as compared to the cubic phase structure may be attributed to its long-term small grain structure and even further continuous grain size refinement due to the progressive phase transformations (tetragonal to monoclinic and/or tetragonal to monoclinic+cubic) during the thermal cycling. The refined grain sizes of the tetragonal phase can enhance the coating crack healing, which would improve the coating toughness. The martensitic phase transformation of the tetragonal phase to monoclinic phase, even at small volume fractions, may significantly toughen the ceramic coatings during the thermal cycling, because of the possible crack arrest due to the formation of the monoclinic phase. The martensitic phase transformation accompanying possible favorable microcracking in the coating may also contribute to the overall coating toughening (ref. 21).

Figure 5 shows the microstructure of several coating systems after furnace cyclic testing. As can be seen from figure $5(\mathrm{a})$, the $\mathrm{ZrO}_{2}-8 \mathrm{wt} \% \mathrm{Y}_{2} \mathrm{O}_{3}$ coating containing the partially stabilized tetragonal phase, still maintains relatively small grain sizes after extended high temperature thermal cycling testing (160 cycles). The coating also failed in a tougher mechanism, which involves severe scale interface delamination and non-brittle type ceramic coating fracture. However, as shown in figures 5(b) and 5(c), the higher yttria dopant content binary YSZ alloys, $\mathrm{ZrO}_{2}-10 \mathrm{~mol} \% \mathrm{Y}_{2} \mathrm{O}_{3}$ and $\mathrm{ZrO}_{2}-30 \mathrm{~mol} \% \mathrm{Y}_{2} \mathrm{O}_{3}$ coatings that possessed the cubic phase structure, experienced a significant grain growth, thus resulting in very low toughness structures. Brittle coating fracture was observed in these extensive grain growth regions after very short thermal cycles (10 to 30 hour cycling).

The oxide defect cluster coatings showed a different grain growth behavior as compared to the binary YSZ coatings under the thermal cyclic condition. As can be seen in figures 5(d) and 5(e), following spalled coating interface regions of the $\mathrm{ZrO}_{2}-6 \mathrm{~mol} \%(\mathrm{Y}, \mathrm{Nd}, \mathrm{Yb}, \mathrm{Sc})_{2} \mathrm{O}_{3}$ (failed at 140 cycles) and $\mathrm{ZrO}_{2}$ $16 \mathrm{~mol} \%(\mathrm{Y}, \mathrm{Sm}, \mathrm{Yb})_{2} \mathrm{O}_{3}$ (failed at 470 cycles), extremely fine grains were observed after the long-term cyclic tests. It should be mentioned that the $\mathrm{ZrO}_{2}-6 \mathrm{~mol} \%(\mathrm{Y}, \mathrm{Nd}, \mathrm{Yb}, \mathrm{Sc})_{2} \mathrm{O}_{3}$ and $\mathrm{ZrO}_{2}-16 \mathrm{~mol} \%$ $(\mathrm{Y}, \mathrm{Sm}, \mathrm{Yb})_{2} \mathrm{O}_{3}$ coatings had a partially stabilized tetragonal structure and a fully stabilized cubic structure, respectively. The cluster dopant coatings had little grain growth even for a high dopant concentration cubic phase system.

The observed grain growth behavior as a function of the dopant concentration for the YSZ binary and multi-component oxide defect cluster coatings is plotted in figure 6 . The data show the grain growth generally increases with increasing total dopant concentrations. Significant grain growth (up to 2 to $5 \mu \mathrm{m}$ in size) was observed for the higher yttria concentration, cubic phase structured yttria-stabilized-zirconia coatings after the furnace cyclic testing. However, the multi-component cluster oxide coatings showed much smaller grain sizes (typically less than $1 \mu \mathrm{m}$ ) at given dopant concentrations. This experimental evidence strongly suggests that the rare earth dopants added to the $\mathrm{ZrO}_{2}$-based coating systems can 
significantly suppress the grain growth at high temperatures, and thus potentially can greatly improve the coating toughness and thermal cycling resistance.

Figure 7 is a high resolution SEM image of a cross-section from a plasma-sprayed $\mathrm{ZrO}_{2}-8 \mathrm{wt} \% \mathrm{Y}_{2} \mathrm{O}_{3}$ coating, showing further grain refinements and toughening by a small amount of monoclinic phase transformations (tetragonal to monoclinic and/or tetragonal to monoclinic + cubic) during the thermal cyclic testing. The grain refinements and phase transformation toughening can greatly contribute to the generally observed excellent cyclic life performance of the $\mathrm{ZrO}_{2}-8 \mathrm{wt} \% \mathrm{Y}_{2} \mathrm{O}_{3}$ (at least at moderately high testing temperatures) and the lower dopant $t^{\prime}$ phase structured defect cluster coatings containing some transformable tetragonal phase. The monoclinic phase content of the plasma-sprayed $\mathrm{ZrO}_{2}-8 \mathrm{wt} \% \mathrm{Y}_{2} \mathrm{O}_{3}$ coating as a function of cycle time at $1163{ }^{\circ} \mathrm{C}$, derived from the X-ray diffraction analysis based on the phase calculation approach described in literature (ref. 22), is shown in figure 8. It can be seen that the monoclinic phase progressively increases with the cycle time which may help to continuously toughen the coating structure and thus provide the excellent cyclic performance.

The test results demonstrate that the design of optimum composition and microstructured thermal barrier coatings can yield excellent cyclic performance. The ceramic coatings using improved oxide cluster compositions may potentially achieve a better toughness and cyclic life, even in a composition region which contains a fully cubic phase, because of their ability to maintain long-term fine grain structures and sintering resistance from low mobility oxide defect clusters (ref. 15). The crack propagation in the coating may also be hindered by the complex stress fields associated with lattice distortions from the nano-sized oxide defect clusters. Since the tetragonal to monoclinic phase transformation may further refine the grain structures and toughen the coating systems, a small amount of the tetragonal phase transformation may be incorporated into the coating systems under the thermal cycling conditions by utilizing advanced compositional and structural heterogeneity design approaches, thus significantly improving the coating delamination and spallation resistance.

\section{Concluding Remarks}

The durability of plasma-sprayed $\mathrm{ZrO}_{2}-\mathrm{Y}_{2} \mathrm{O}_{3}$ binary coatings and advanced low conductivity multicomponent cluster oxide coatings was evaluated using conventional furnace cyclic oxidation tests at $1163{ }^{\circ} \mathrm{C}$. The results have shown that the oxide defect cluster coatings have the potential to achieve significantly better cyclic performance than the binary $\mathrm{ZrO}_{2}-\mathrm{Y}_{2} \mathrm{O}_{3}$ coatings because of their improved high temperature stability, reduced grain growth, and thus increased toughness structures.

The ceramic coating cyclic life generally decreases as the dopant concentration increases presumably due to the reduced fraction of tetragonal phase and the increased fraction of the cubic phase. The fullystabilized-cubic phase usually shows an enhanced grain growth behavior, and also lacks the further grainrefining and toughening mechanisms by the tetragonal to monoclinic phase transformation present in a partially-stabilized-tetragonal phase. Therefore, very low toughness coating structures are often observed in high-dopant-concentration coatings, and especially for the $\mathrm{ZrO}_{2}-\mathrm{Y}_{2} \mathrm{O}_{3}$ binary coatings.

Although the advanced multi-component oxide defect cluster coatings followed a similar trend as the $\mathrm{ZrO}_{2}-\mathrm{Y}_{2} \mathrm{O}_{3}$ binary coating systems in the furnace cyclic behavior (where the coating cyclic life decreases with increasing the total dopant concentration), the oxide cluster coatings showed promise for achieving better cyclic life than the binary $\mathrm{ZrO}_{2}-\mathrm{Y}_{2} \mathrm{O}_{3}$ coatings with equivalent dopant concentrations. Cyclic life comparable to (or better than) that of the low dopant $\mathrm{ZrO}_{2}-8 \mathrm{wt} \% \mathrm{Y}_{2} \mathrm{O}_{3}$ coating has been observed even for some medium-high-dopant-concentration, and very low-conductivity coating systems. Advanced processing and composition optimization will be used to further improve the durability of the high performance ceramic thermal barrier coating systems. 


\section{References}

1. D. Zhu and R.A. Miller, "Thermophysical and Thermomechanical Properties of Thermal Barrier Coating Systems," Ceram. Eng. Sci. Proc., 21 (2000), pp. 623-633.

2. D. Zhu and R.A. Miller, "Thermal Barrier Coatings for Advanced Gas-Turbine Engines," MRS Bulletin, 27 (2000), pp. 43-47.

3. M.J. Malony, "Thermal Barrier Coating Systems and Materials," US Pat. No. 6,284,323, September 2001.

4. R. Subramanian, "Thermal Barrier Coating Having High Phase Stability,” US Pat. No. 6,387,539, May 2002.

5. R. Vassen, X. Cao, F. Tietz, D. Basu, and D. Stöver, "Zirconates as New materials for Thermal Barrier Coatings," Journal of the American Ceramic Society, 83 (2000), pp. 2023-2028.

6. Jie Wu, Xuezheng Wei, Nitin P. Padture, Paul G. Klemens, Maurice Gell, Eugenio García, Pilar Miranzo, and Maria I. Osendi, "Low-Thermal-Conductivity Rare-Earth Zirconates for Potential Thermal-Barrier-Coating Applications," Journal of the American Ceramic Society, 85 (2002), pp. 3031-3035.

7. Henry Lehmann, Dieter Pitzer, Gerhard Pracht, Robert Vassen, and Detlef Stöver, "Thermal Conductivity and Thermal expansion Coefficients of the Lanthanum Rare-Earth-Element Zirconate System," Journal of the American Ceramic Society, 86 (2003), pp. 1338-1344.

8. Ulrich Bast, and Eckart Schumann, "Development of Novel Oxide Materials for TBCs," Ceramic Eng. Sci. Proc., 23 (2002), pp. 525-532.

9. R. Gadow, and M. Lischka, "Lanthanum Hexaaluminate-Novel Thermal Barrier Coatings for Gas Turbine Applications-Materials and Process Development", Surface and Coatings Technology, 151-152 (2002), pp. 392-399.

10. Jie Wu, Nitin P. Padture, Paul G. Klemens, Maurice Gell, Eugenio García, Pilar Miranzo, and Maria

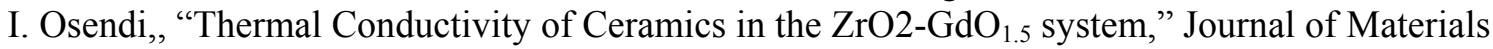
Research, 17 (2002), pp. 3193-3200.

11. Dongming Zhu, Narottam P. Bansal, and Robert A. Miller, "Thermal Conductivity and Stability of Hafnia- and Zirconate-Based Materials for $1650^{\circ} \mathrm{C}$ Thermal/Environmental Barrier Coating Applications," Ceramic Transactions, 153 (2003). Also NASA/TM-2003-212544.

12. Dongming Zhu, and Robert A. Miller, "Sintering and Creep Behavior of Plasma-Sprayed Zirconia and Hafnia-Based Thermal Barrier Coatings," Surface and Coatings Technology, 108-109 (1998), pp. $114-120$.

13. D. Zhu and R.A. Miller, "Defect Cluster Design Considerations in Advanced Thermal Barrier Coatings,” NASA Ultra-Efficient Engine Technology (UEET) Meeting Presentation, NASA Glenn Research Center, Cleveland, Ohio, April 1999.

14. Dongming Zhu, and Robert A. Miller, "Low Conductivity and Sintering Resistant Thermal Barrier Coatings," US Provisional Patent Application Serial No. 60/263,257, USA; US Patent Application Serial No. 09/904,084, USA, January 2001.

15. Dongming Zhu, and Robert A. Miller, "Thermal Conductivity and Sintering Behavior of Advanced Thermal Barrier Coatings,” Ceramic Eng. Sci. Proc., Vol. 23 (2002), 457-468. Also NASA/TM2002-211481.

16. John R. Nicholls, K.J. Lawson, A. Johnstone and D.S. Rickerby, "Methods to reduce the thermal conductivity of EB-PVD TBCs," 151-152 (2002), pp. 383-391.

17. Dongming Zhu, Yuan L. Chen, and Robert A. Miller, "Defect Clustering and Nano-phase Structure Characterization of Multicomponent Rare-Earth Oxide Doped Zirconia-Yttria Thermal Barrier Coatings," Ceramic Eng. Sci. Proc., Vol. 24 (2003). Also NASA/TM-2003-212480.

18. Dongming Zhu, and Robert A. Miller, "Hafnia-Based Materials Development for Advanced Thermal/Environmental Barrier Coating Applications," in Research and Technology 2003, NASA Glenn Research Center, NASA TM, in press. 
19. Dongming Zhu, James A. Nesbitt, Terry R. McCue, Charles A. Barrett, and Robert A. Miller, "Furnace Cyclic Oxidation Behavior of Multi-Component Low Conductivity Thermal Barrier Coatings," Ceramic Eng. Sci. Proc., Vol. 23 (2002), 533-545.

20. James A. Nesbitt, Dongming Zhu, Robert A. Miller and Charles A. Barrett, "Failure Morphologies of Cyclically Oxidized ZrO2-Based Thermal Barrier Coatings," Materials at High temperatures, 20 (4) 2003, 507-518

21. Robert A. Miller, Ralph G. Garlick, and J. L. Smialek, "Phase Distributions in Plasma-Sprayed Zirconia-Yttria," American Ceramic Society Bulletin, vol. 62, pp. 1355-1358, 1983.

22. Robert A. Miller, James L. Smialek, and R. G. Garlick, "Phase Stability in Plasma-Sprayed, Partially Stabilized Zirconia-Yttria," in Advances in Ceramics: Science and Technology of Zirconia, vol. 3, A.H. Heuer and L.W. Hobbs, Eds. Columbus, Ohio: The American Ceramic Society, 1981, pp. 241-253.

Table 1. Thermal conductivity and coefficients of thermal expansion of baseline $\mathrm{ZrO}_{2}-8 \mathrm{wt} \% \mathrm{Y}_{2} \mathrm{O}_{3}$ and multi-component defect cluster coatings

\begin{tabular}{|l|c|c|c|}
\hline \multirow{2}{*}{} & \multicolumn{2}{|c|}{ Thermal conductivity (W/m-K) } & \multirow{2}{*}{$\begin{array}{c}\text { Coefficient of } \\
\text { thermal expansion }(\mathrm{m} / \mathrm{m}-\mathrm{K})\end{array}$} \\
\cline { 2 - 3 } & As-processed & $\begin{array}{c}\text { After } 20 \text { hour } \\
\text { exposure at } \\
1316^{\circ} \mathrm{C}\end{array}$ & (average values from 25 to $\left.1400{ }^{\circ} \mathrm{C}\right)$ \\
\hline $\begin{array}{l}\text { Baseline } \mathrm{ZrO}_{2-} \\
8 \mathrm{wt} \% \mathrm{Y}_{2} \mathrm{O}_{3}\end{array}$ & 1.0 & 1.3 to 1.5 & 10.5 to $11.0 \times 10^{-6}$ \\
\hline $\begin{array}{l}\text { Oxide defect } \\
\text { cluster coating }\end{array}$ & 0.5 to 0.7 & 0.6 to 1.1 & 11.5 to $13.5 \times 10^{-6}$ \\
\hline
\end{tabular}




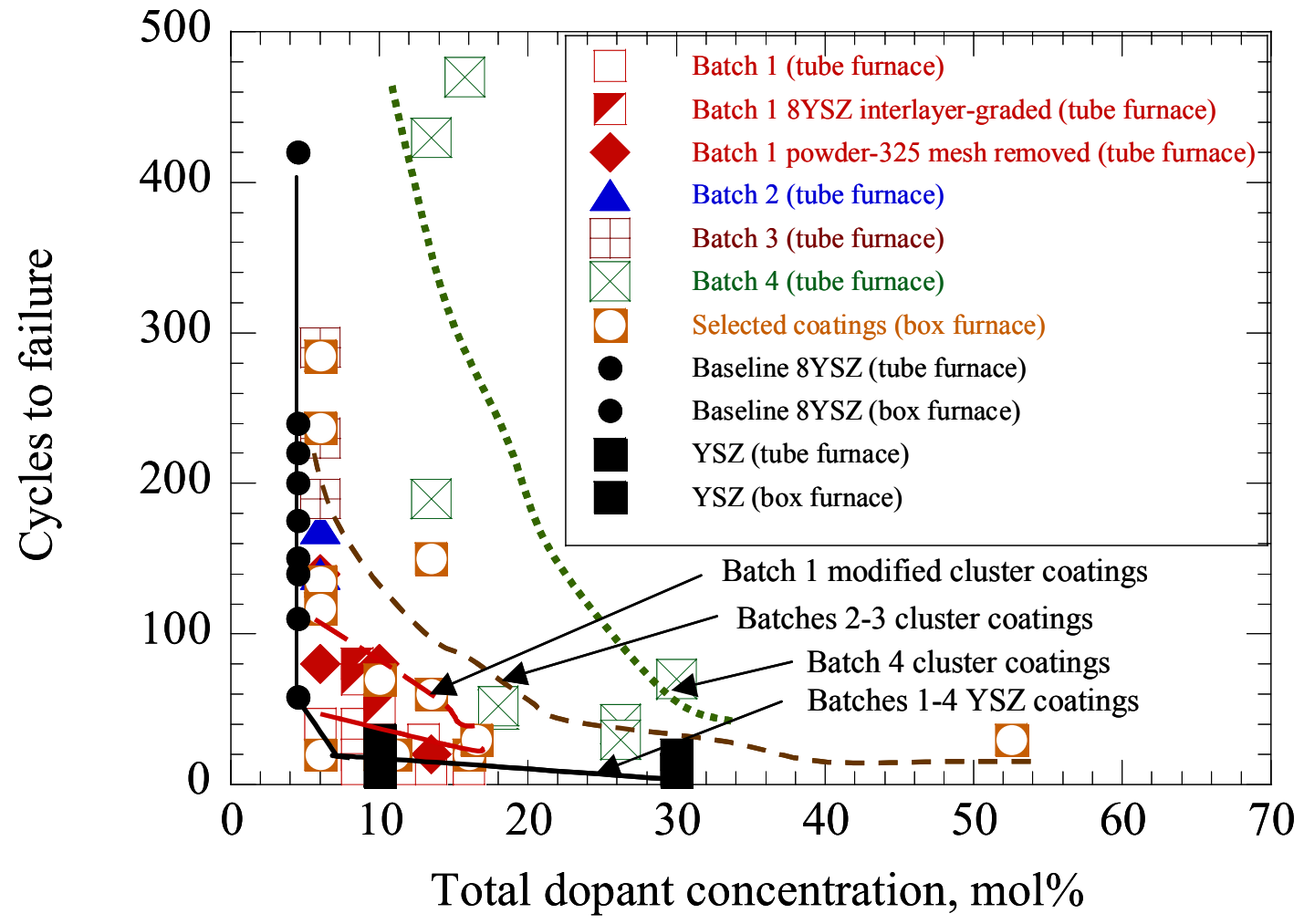

Figure 1. Furnace cyclic oxidation test results showing the coating cycles to failure as a function of total dopant concentration for plasma-sprayed $\mathrm{ZrO}_{2}$-based thermal barrier coatings. The coating cyclic life generally decreases with increasing total dopant concentration, and the multi-component rare earth cluster oxide coatings showed evidence to have better cyclic durability than yttria-stabilized-zirconia (YSZ) binary coatings at given dopant concentrations. 

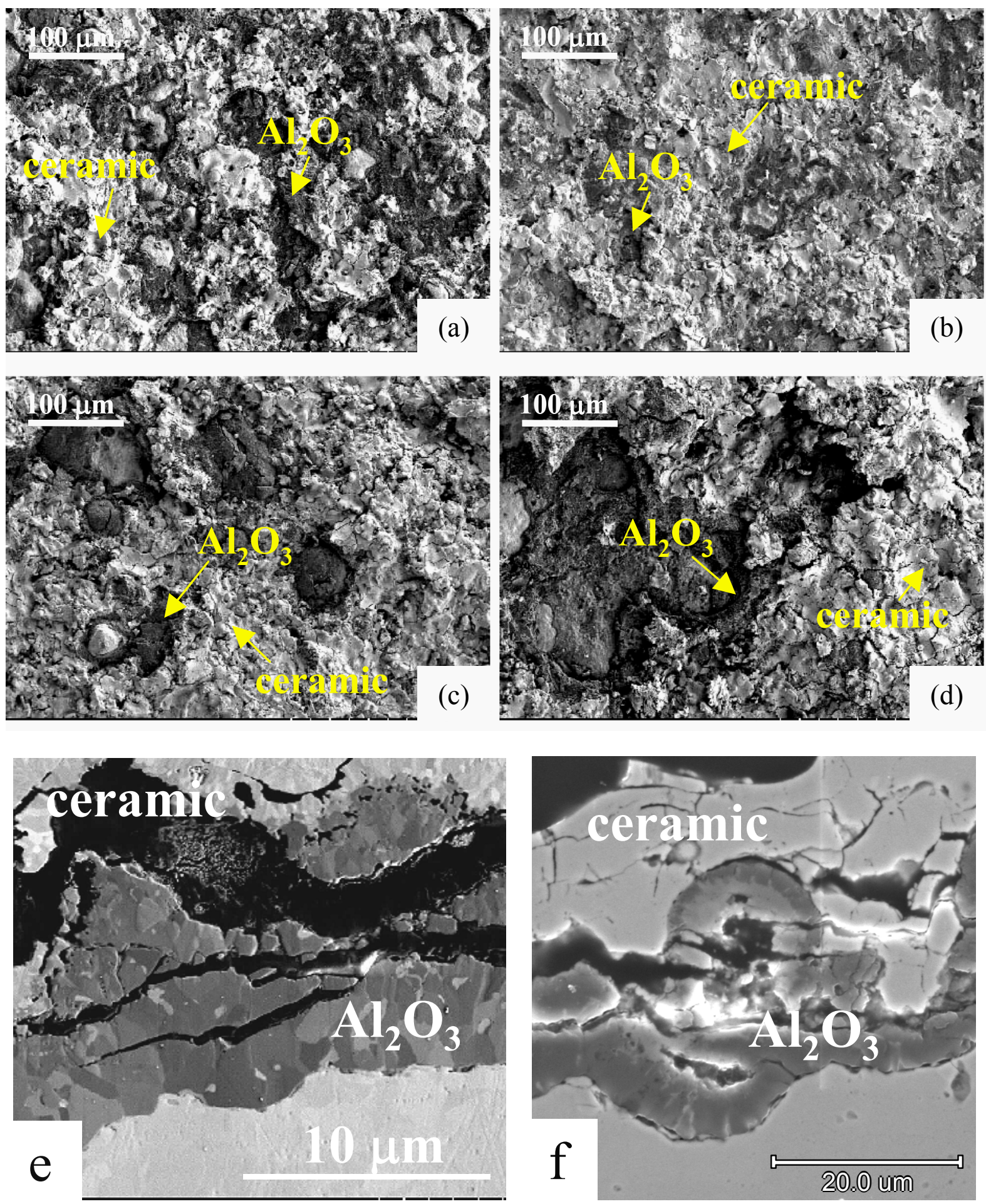

Figure 2. SEM images of the spalled coating surface morphologies and cross-sections showing a mixed failure mode involving both the ceramic failure and scale interface failure after furnace cyclic testing.

(a) $\mathrm{ZrO}_{2}-8 \mathrm{wt} \% \mathrm{Y}_{2} \mathrm{O}_{3}\left(\mathrm{ZrO}_{2}-4.55 \mathrm{wt} \% \mathrm{Y}_{2} \mathrm{O}_{3}\right)$; (b) $\mathrm{ZrO}_{2}-30 \mathrm{~mol} \% \mathrm{Y}_{2} \mathrm{O}_{3}$; (c) $\mathrm{ZrO}_{2}-6 \mathrm{~mol} \%(\mathrm{Y}, \mathrm{Nd}, \mathrm{Yb}, \mathrm{Sc})_{2} \mathrm{O}_{3}$;

(d) $\mathrm{ZrO}_{2}-16 \mathrm{~mol} \%(\mathrm{Y}, \mathrm{Sm}, \mathrm{Yb})_{2} \mathrm{O}_{3}$; (e) Cross-section of $\mathrm{ZrO}_{2}-8 \mathrm{wt} \% \mathrm{Y}_{2} \mathrm{O}_{3}$; (f) Cross-section of $\mathrm{ZrO}_{2}-6 \mathrm{~mol} \%$ $(\mathrm{Y}, \mathrm{Gd}, \mathrm{Yb})_{2} \mathrm{O}_{3}$. 


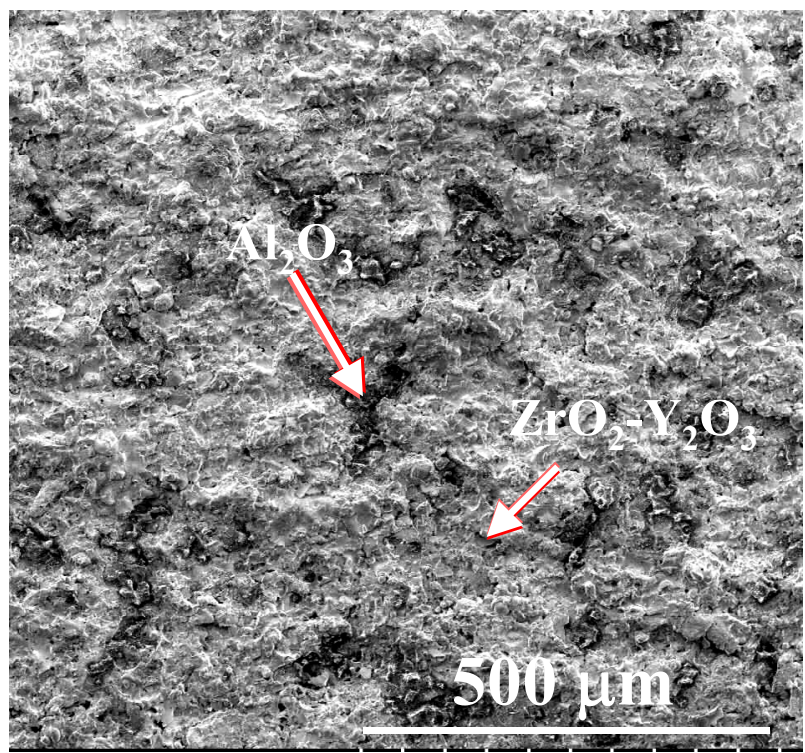

(a)

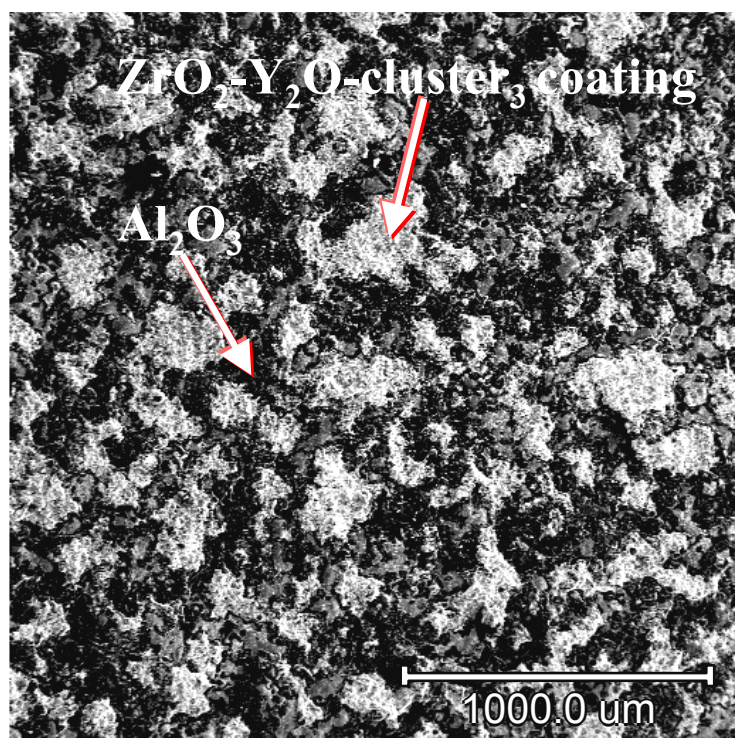

(b)

Figure 3. SEM micrographs showing the spalled thermal barrier coatings on the substrates after the furnace thermal cyclic testing (dark and bright regions are exposed alumina scales, and the remaining attached ceramic top coats, respectively). (a) Low toughness $\mathrm{ZrO}_{2}-30 \mathrm{~mol} \% \mathrm{Y}_{2} \mathrm{O}_{3}$, cyclic life 20 cycles, showing the predominant ceramic failure; (b) $\mathrm{ZrO}_{2}-13.5 \mathrm{~mol} \%(\mathrm{Y}, \mathrm{Nd}, \mathrm{Yb})_{2} \mathrm{O}_{3}$ coating, with cyclic life of 430 cycles, showing a more predominant interface scale failure. 


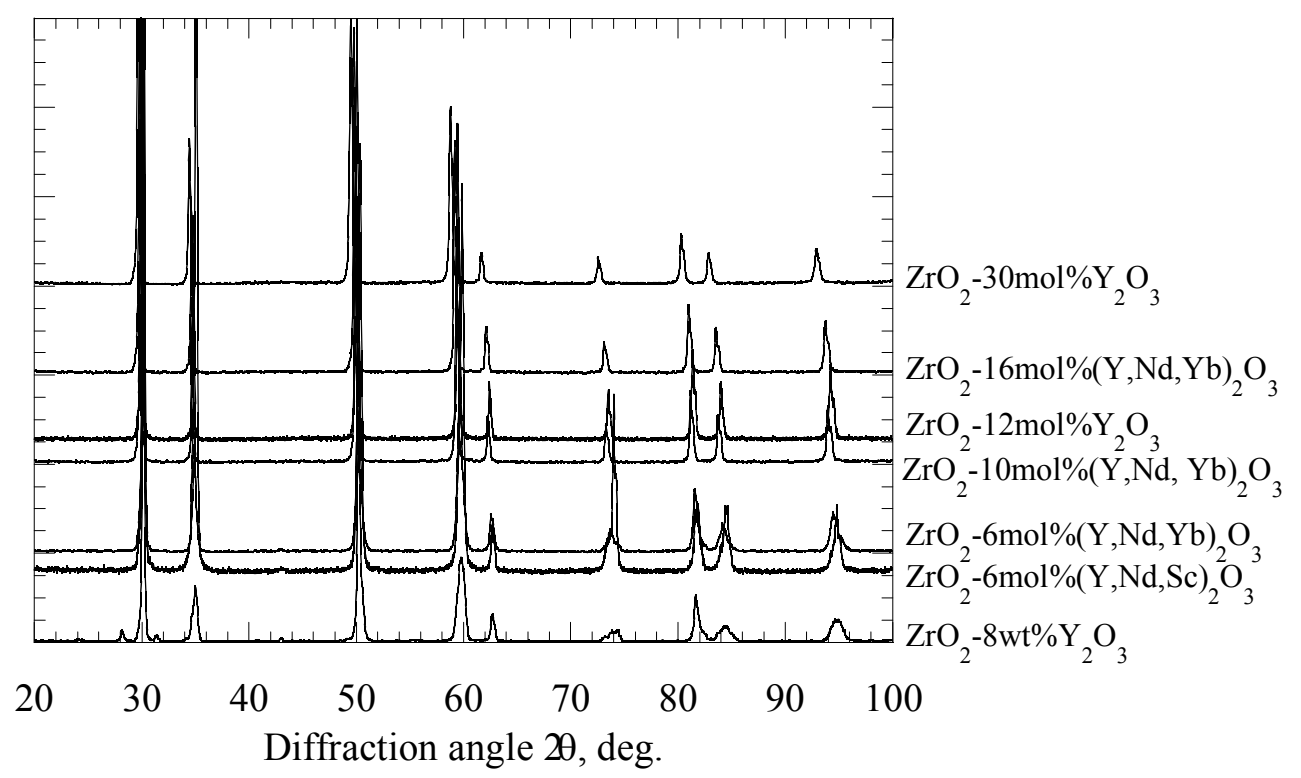

(a)

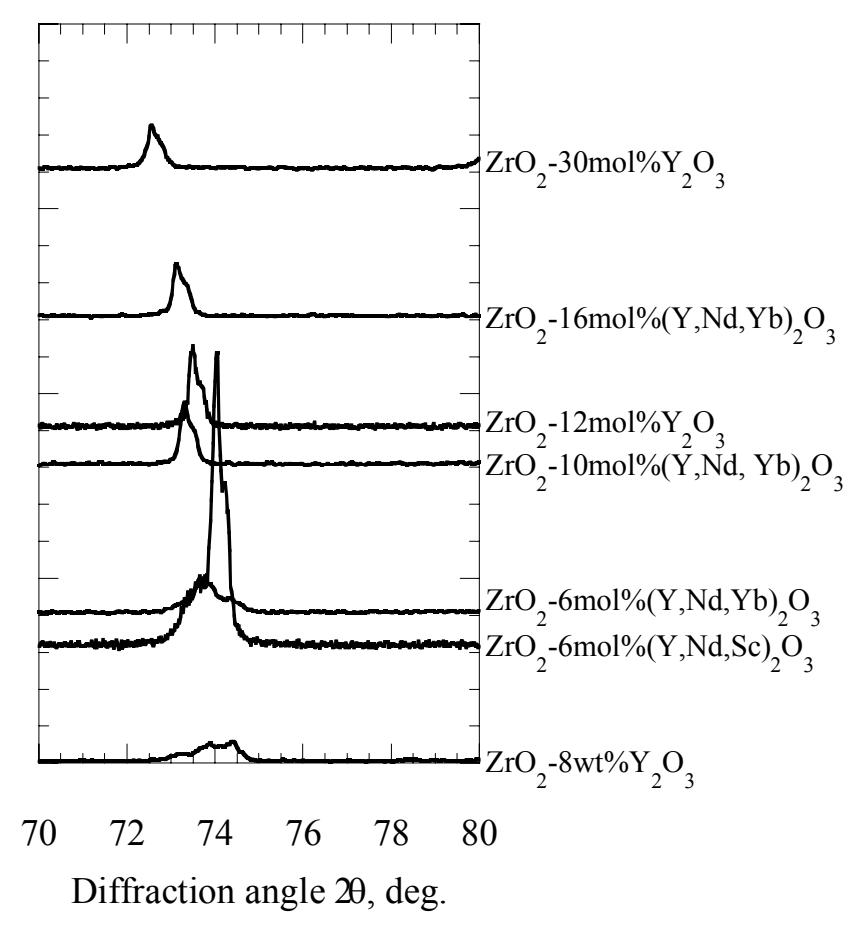

(b)

Figure 4. X-ray diffraction patterns for various oxide thermal barrier coatings showing the phase structure

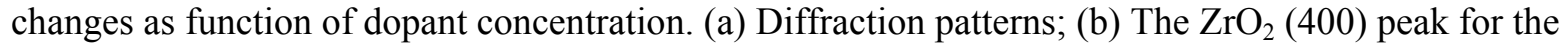
doped oxides. 


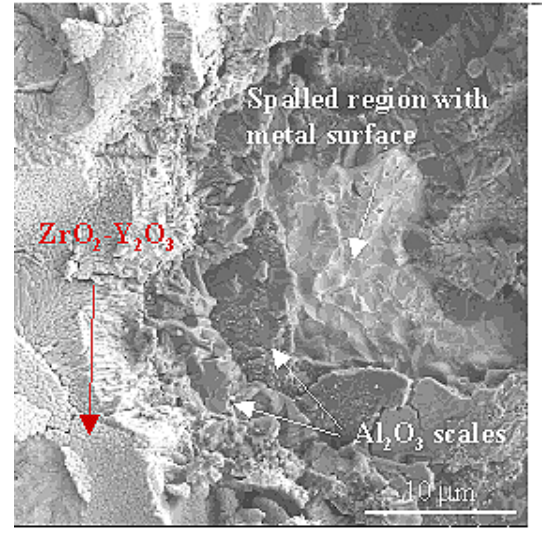

(a)

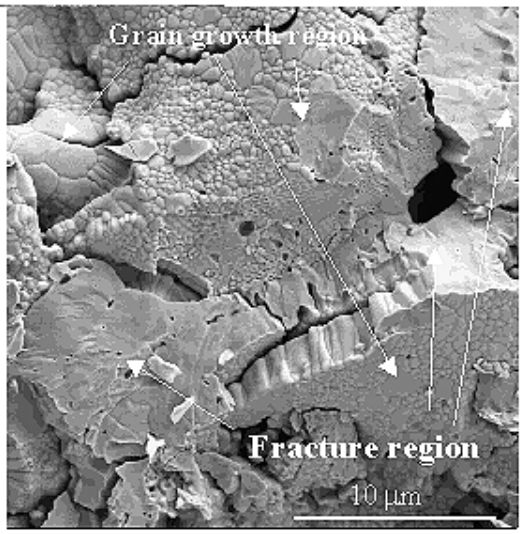

(b)

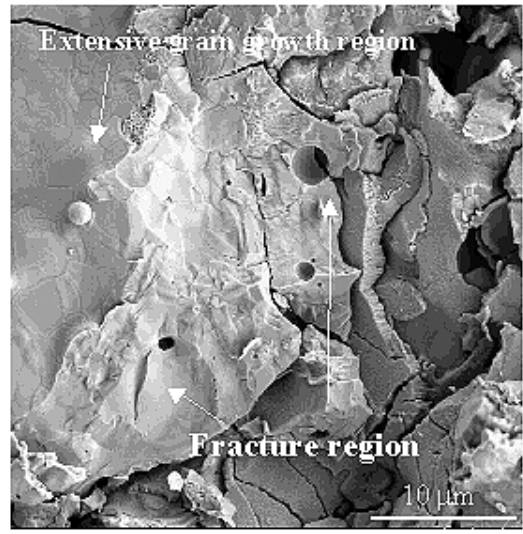

(c)

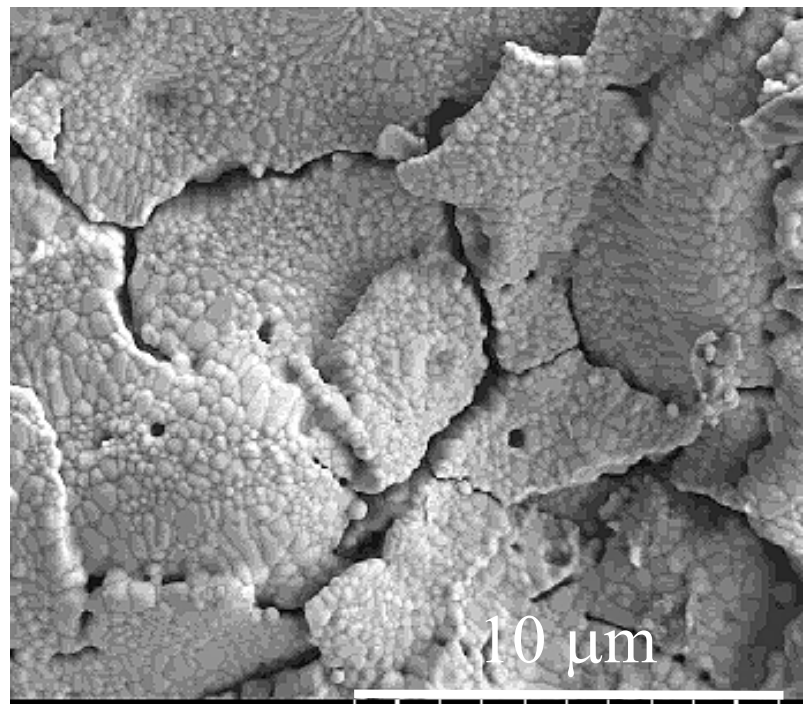

(d)

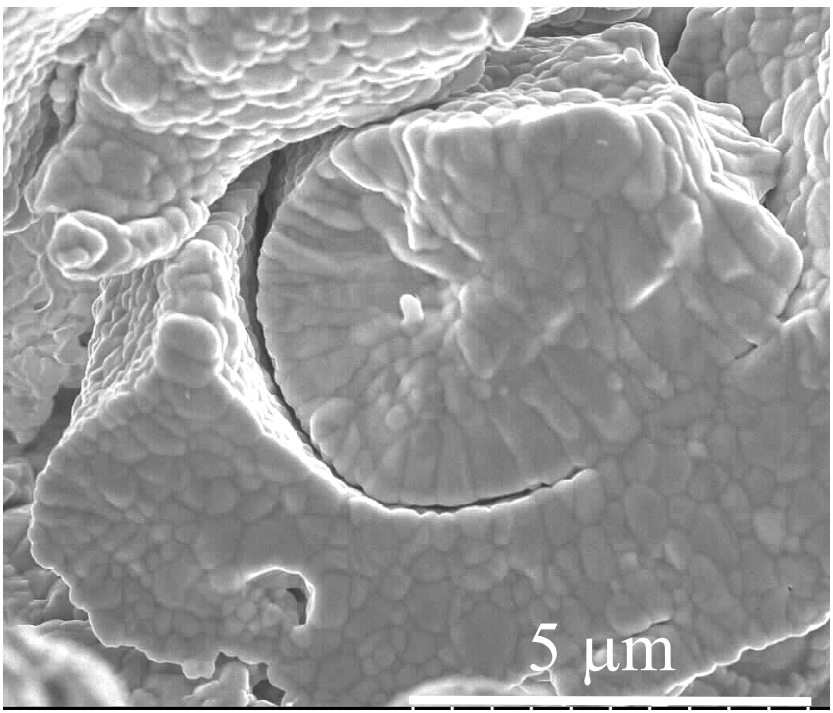

(e)

Figure 5. Scanning electron micrographs showing the ceramic coating spalling/fracture morphologies near the ceramic/bond coat interface region after furnace thermal cyclic testing. (a) $\mathrm{ZrO}_{2}-8 \mathrm{wt} \% \mathrm{Y}_{2} \mathrm{O}_{3}$, 160 cycles; (b) $\mathrm{ZrO}_{2}-10 \mathrm{~mol} \% \mathrm{Y}_{2} \mathrm{O}_{3}, 30$ cycles; (c) $\mathrm{ZrO}_{2}-30 \mathrm{~mol}_{0} \mathrm{Y}_{2} \mathrm{O}_{3}, 10$ cycles; (d) $\mathrm{ZrO}_{2}-6 \mathrm{~mol} \%(\mathrm{Y}, \mathrm{Nd}, \mathrm{Yb}, \mathrm{Sc})_{2} \mathrm{O}_{3}, 140$ cycles; (e) $\mathrm{ZrO}_{2}-16 \mathrm{~mol} \%(\mathrm{Y}, \mathrm{Sm}, \mathrm{Yb})_{2} \mathrm{O}_{3}, 470$ cycles. 


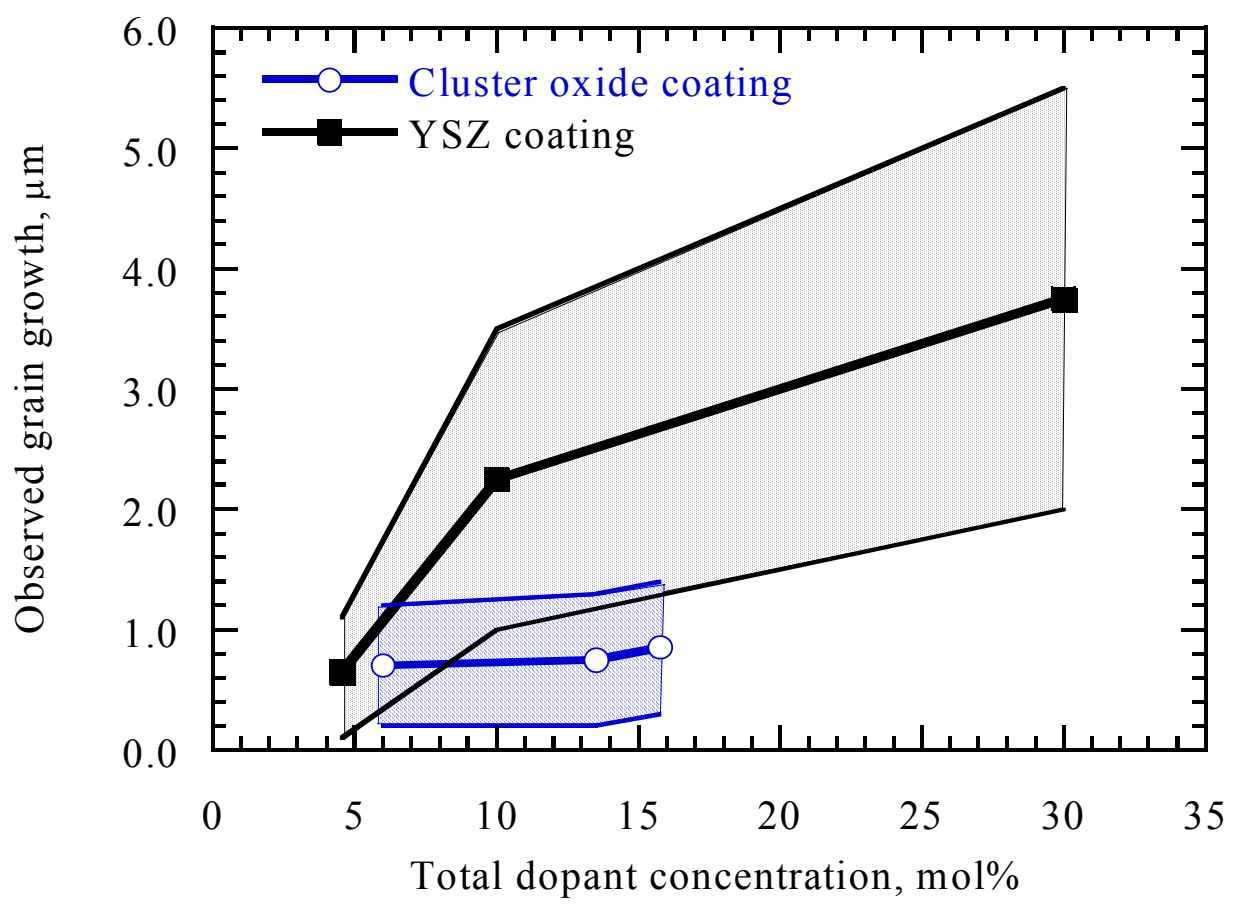

Figure 6. Ceramic coating grain growth after the furnace cyclic oxidation testing for the multi-component oxide cluster coating systems and the yttria-zirconia binary coating systems. The shadowed areas in the plot show the approximate grain size distribution bands observed in many noticeable coating grain growth regions. 


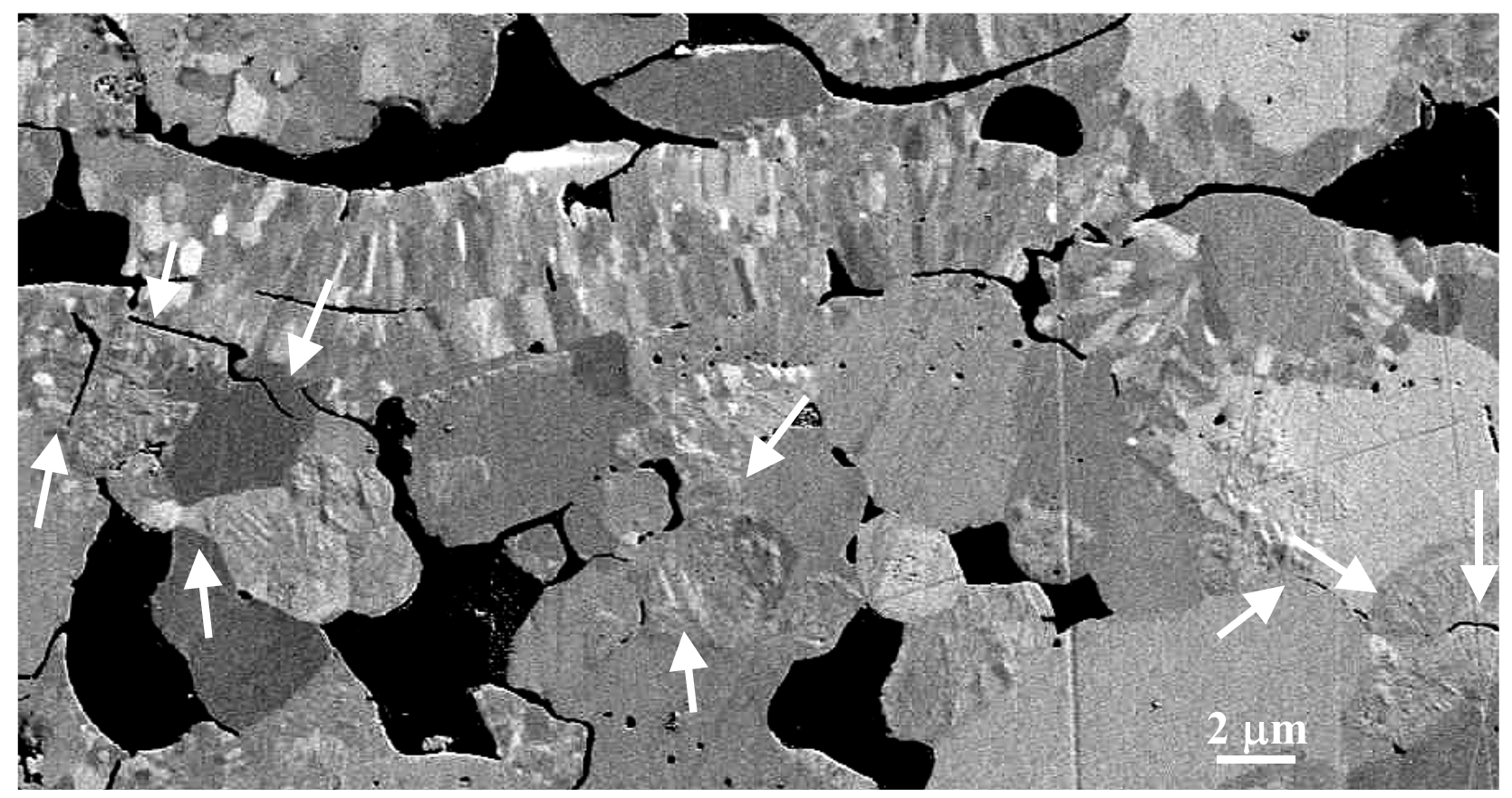

Figure 7. High resolution SEM images showing the overall fine grain structures of $\mathrm{ZrO}_{2}-8 \mathrm{wt} \% \mathrm{Y}_{2} \mathrm{O}_{3}$. Further grain refinements and toughening by a small amount of monoclinic phase transformations (tetragonal to monoclinic and/or tetragonal to monoclinic+cubic) during the thermal cyclic testing can contribute to the excellent cyclic life performance of this baseline coating and other lower dopant oxide defect cluster $t^{\prime}$ phase structured coatings. The arrows in this micrograph indicate the possible crack arrests and the ceramic toughening by the formation of the monoclinic phase (seen as rippled needle-like structure). 


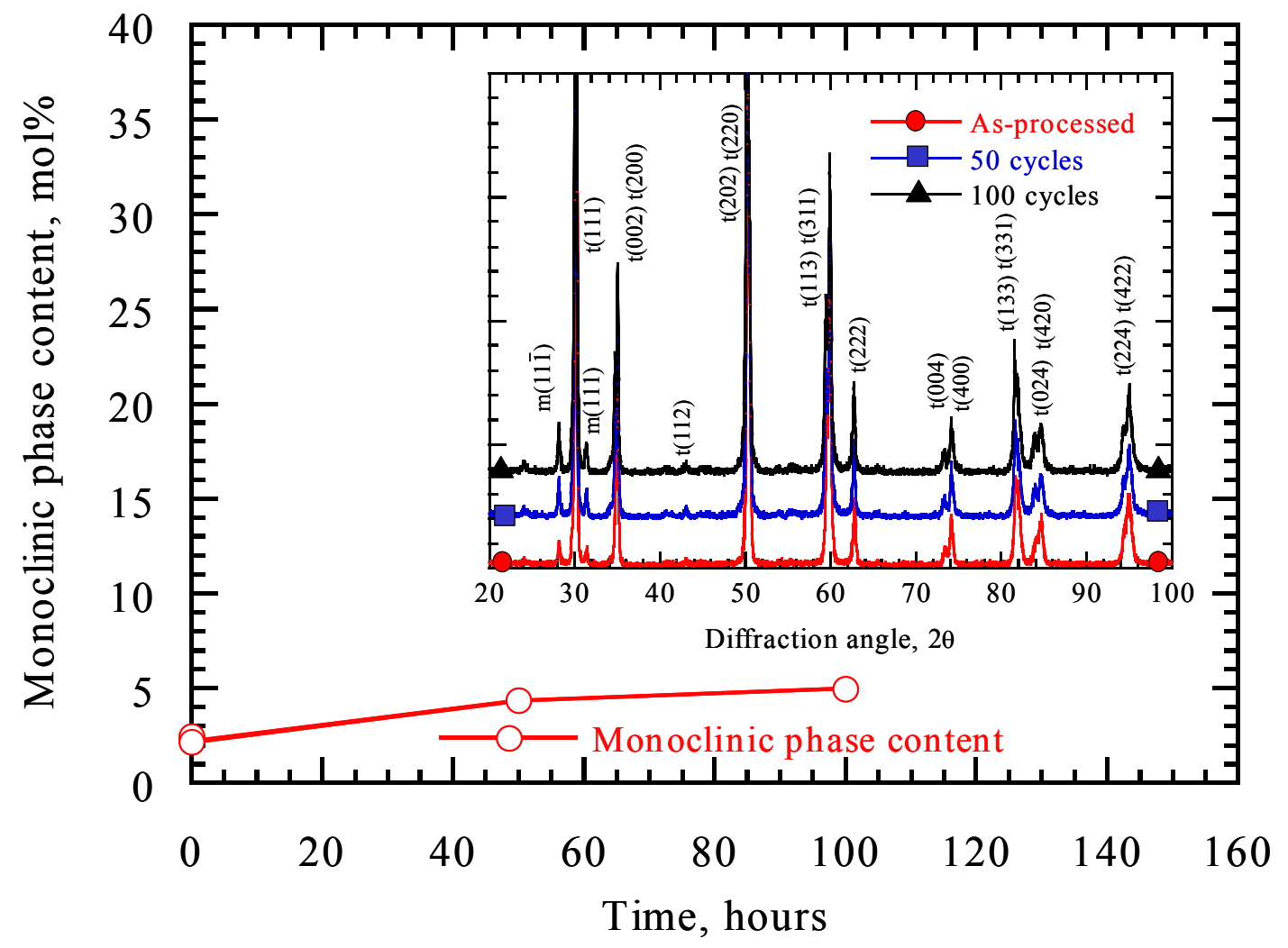

Figure 8. The monoclinic phase content of the plasma-sprayed $\mathrm{ZrO}_{2}-8 \mathrm{wt} \% \mathrm{Y}_{2} \mathrm{O}_{3}$ coating as a function of cycle time at $1163{ }^{\circ} \mathrm{C}$, derived from the $\mathrm{X}$-ray diffraction analysis. Insert is the $\mathrm{X}$-ray diffraction patterns for $\mathrm{ZrO}_{2}-8 \mathrm{wt} \% \mathrm{Y}_{2} \mathrm{O}_{3}$ coating specimens under conditions of as-processed, and after testing for 50 and 100 cycles at $1163{ }^{\circ} \mathrm{C}$ in a tube furnace, respectively, showing the monoclinic phase increases progressively with the cycle time. 

Public reporting burden for this collection of information is estimated to average 1 hour per response, including the time for reviewing instructions, searching existing data sources, gathering and maintaining the data needed, and completing and reviewing the collection of information. Send comments regarding this burden estimate or any other aspect of this collection of information, including suggestions for reducing this burden, to Washington Headquarters Services, Directorate for Information Operations and Reports, 1215 Jefferson Davis Highway, Suite 1204, Arlington, VA 22202-4302, and to the Office of Management and Budget, Paperwork Reduction Project (0704-0188), Washington, DC 20503.

\begin{tabular}{|l|l|l|}
\hline 1. AGENCY USE ONLY (Leave blank) & $\begin{array}{c}\text { 2. REPORT DATE } \\
\text { July } 2004\end{array}$ & $\begin{array}{r}\text { 3. REPORT TYPE AND DATES COVERED } \\
\text { Technical Memorandum }\end{array}$ \\
\hline
\end{tabular}

\section{TITLE AND SUBTITLE}

Furnace Cyclic Oxidation Behavior of Multi-Component Low Conductivity Thermal Barrier Coatings

\section{AUTHOR(S)}

Dongming Zhu, James A. Nesbitt, Charles A. Barrett, Terry R. McCue, and Robert A. Miller

\section{PERFORMING ORGANIZATION NAME(S) AND ADDRESS(ES)}

National Aeronautics and Space Administration

John H. Glenn Research Center at Lewis Field

Cleveland, Ohio 44135-3191

\section{FUNDING NUMBERS}

WBS-22-714-04-05

1L162211A47A

\section{SPONSORING/MONITORING AGENCY NAME(S) AND ADDRESS(ES)}

National Aeronautics and Space Administration

Washington, DC 20546-0001

and

U.S. Army Research Laboratory

Adelphi, Maryland 20783-1145
8. PERFORMING ORGANIZATION REPORT NUMBER

E-14434

\section{SUPPLEMENTARY NOTES}

Dongming Zhu, U.S. Army Research Laboratory, NASA Glenn Research Center; James A. Nesbitt, Charles A. Barrett, and Robert A. Miller, Glenn Research Center; and Terry R. McCue, QSS Group, Inc., Cleveland, Ohio 44135.

Responsible person, Dongming Zhu, organization code 5160, 216-433-5422.

\section{2a. DISTRIBUTION/AVAILABILITY STATEMENT}

Unclassified - Unlimited

Subject Categories: 23, 26, and 27

Available electronically at http://gltrs.grc.nasa.gov

This publication is available from the NASA Center for AeroSpace Information, 301-621-0390.
10. SPONSORING/MONITORING AGENCY REPORT NUMBER

NASA TM-2004-212962

ARL-TR-3260

\section{ABSTRACT (Maximum 200 words)}

Ceramic thermal barrier coatings will play an increasingly important role in advanced gas turbine engines because of their ability to further increase engine operating temperatures and reduce cooling, thus helping achieve future engine low emission, high efficiency and improved reliability goals. Advanced multi-component zirconia-based thermal barrier coatings are being developed using an oxide defect clustering design approach to achieve the required coating low thermal conductivity and high temperature stability. Although the new composition coatings were not yet optimized for cyclic durability, an initial durability screening of the candidate coating materials was conducted using conventional furnace cyclic oxidation tests. In this paper, furnace cyclic oxidation behavior of plasma-sprayed zirconia-based defect cluster thermal barrier coatings was investigated at $1163{ }^{\circ} \mathrm{C}$ using $45 \mathrm{~min}$ hot cycles. The ceramic coating failure mechanisms were studied using scanning electron microscopy (SEM) combined with X-ray diffraction (XRD) phase analysis after the furnace tests. The coating cyclic lifetime is also discussed in relation to coating processing, phase structures, dopant concentration, and other thermo-physical properties.

\section{SUBJECT TERMS}

Thermal barrier coatings; Oxide grain growth; Oxide defect clusters; Thermal conductivity

17. SECURITY CLASSIFICATION OF REPORT

Unclassified

18. SECURITY CLASSIFICATION
OF THIS PAGE
Unclassified

Unclassified
15. NUMBER OF PAGES

22

16. PRICE CODE 

